\title{
地四記入法を用いた散策経路選択と個人特性との関連に関する研究
A STUDY ON THE RELATIONSHIP BETWEEN STROLLING COURSE SELECTION AND PERSONAL FEATURE BY A METHOD OF DRAWING ONA MAP

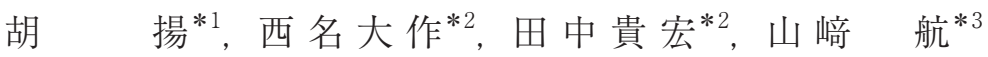 \\ Yang HU, Daisaku NISHINA, Takahiro TANAKA \\ and Wataru YAMASAKI
}

\begin{abstract}
As a study for pedestrian's behavior, course selection factors have been studied variously so far. However, studies from the perspective of personal feature have not been sufficiently accumulated. The purpose of this study is to clarify the relationship between course selection behavior and the personal feature. The course selection experiments were carried out by the method of drawing courses on 12 blank maps with various streets patterns. As the result, the subjects who tended to walk a long distance and prefer narrow and complexed streets were most interested in strolling and they also have good spatial cognitive abilities.
\end{abstract}

Keywords : Course Selection, Method of Drawing on a Map, Personal feature, Streets Patterns 経路選択，地図記入法，個人特性，街路パターン

\section{1. はじめに}

経路選択に関連する要因として、「環境要素」と「歩行者の個人 特性」が挙げられている ${ }^{1)}$ 。「環境要素」は、街路網や街路の形状、 施設など移動を行う物理的環境要素の条件である。環境要素を経路 選択の要因として検討した研究成果は多く報告されている。例えば 斎藤ら ${ }^{2)}$ は、歩行者の経路選択頻度と物理的環境との関連を考察し、 歩道幅員が広く店舗密度が高い街路が選択されや寸い傾向を示して いる。また、竹内ら ${ }^{3)}$ は、歩行者に好まれる街路の特徴を把握する ため、最短距離から乘離した経路ほどより選好される街路であると 考え、その乘離した要因を検討することで、歩道形態と種別、商店 の有無などが経路選択に影響することを示している。

一方、「歩行者の個人特性」は、人間の個性や心身などの条件で ある。個人差は経路選択行動に大きく影響することが指摘されてい る。例えば三浦ら ${ }^{4)}$ 5) $は$ 空間構造把握の度合いによって被験者を3 グループに分類し、目的地を教示した往復探索歩行実験を実施し、 各グループの歩行距離や空間情報利用等の行動を検討した結果から、 空間構造把握度の低いグループは経路が長く、探索をする際に迷い やすいと思った場所が多いことを把握している。西應ら ${ }^{6)}$ はアンケ 一ト調査で被験者を、格子状街路を得意とするタイプと不規則街路 を得意とするタイプに分類し、この2種類の街路における被験者の行 動解析により、空間構成の相違と被験者の空間理解の傾向との関係 を検討している。その結果、規則的な街路を得意とする被験者は方
向を手掛かりに進んでおり、経路距離も比較的正確に記憶している のに対し、不規則街路を得意とする被験者は距離よりも各コーナー の角度を関連づけて記憶し手掛かりにして進んでいると予想してい る。人間は経験や生来の空間感覚、好みなど各人で異なる特性を有 しており、多くの人々に良好な街路空間を提供するためには、個人 特性についても考慮する必要があるといえる。

しかしながら、経路選択要因に関する先行研究の多くは「外部状 況」に着目しており、個人特性の側面からの検討はまだ十分になさ れていない。そこで本研究では後者に焦点を当て、経路選択行動の 一端と個人特性との関連について明らかにすることを目的とする。

また、従来の研究は主に実空間を対象としているが、実空間には 様々な環境要素が混在している。したがって、個人特性による影響 を検討しようとした場合、実空間では異なる環境要素に対する嗜好 や価值観による影響が大きく、街路そのものに対する関心の違いに よる影響は充分に明らかになっていないのではないかと考えられる。 ここで、街路そのものとは、街路の形状や街路同士の繋がり方、街 路パターンであり、街路空間を構成する最も重要な、基整的要素で あると言える。このような観点から本研究では、街路そのものと人 間の選択行動との関係を明確に把握するため、経路を地図上に記入 させる方法（以下、地図記入法）を用いる。これにより、実空間の 数多の要素による影響を除外し、街路空間を単純化させ、街路その ものの呈示が可能になるものと考えた。地図は日常的なツールとし
*1 広島大学大学院工学研究科 大学院生 · 修士 (工学)

*2 広島大学大学院工学研究科教授. 工博

*3 鉄道建設・運輸施設整備支援機構 修士 (工学)
Grad. Student, Graduate School of Eng., Hiroshima University, M.Eng.

Prof., Graduate School of Eng., Hiroshima University, Dr.Eng.

Japan Railway Construction, Transport and Technology Agency, M.Eng. 
て広範に利用されており、いまや人々が空間的知識を獲得するため の有力な情報源になっている7 ${ }^{7)}$ このことから、個人が蓄積した習 慣や選択の傾向などは地図上に記入される経路に反映されるものと 予想した。

加えて、本研究で地図記入法を採用する理由として、経路選択行 動が街路パターンの違いによって変化する可能性が挙げられる。例 えば規則的な街路と不規則な街路では、前者を好む者や後者を好む 者が存在することが予想される。したがって、単一の街路パターン を対象とするのではなく、様々な街路パターンを選び出し、対象と することにより、経路選択と個人特性との関連をより明確に把握で きることを期待している。

以上の観点から本研究では、様々な都市の街路パターンを対象と して、街路そのものの形状と空間の接続関係に情報が単純化された 白地図を用い、地図記入法による経路選択実験を行う。得られた結 果から、人々がどのように街路を捉えて経路を選択するのか、異な る経路選択傾向の生じる原因を個人特性の面から解明し、さらに個 人の行動、個人の特性、個人の考えの相互関係を明らかにすること で、経路選択行動の一端を把握することを意図している。なお、地 図上に記入した経路通りに、実際にどの程度人々が行動するのかに ついて、将来的には検討する必要があるが、街路そのものに対する 認識における個人の違いを明らかにすることも、今後の経路選択行 動に関する研究に有意義な示唆を与えると共に、広く人間行動を理 解する上でも有用な情報を提供するものと考えられる。

本論文では、2章で経路選択実験について概略を記述し、3章では 経路選択結果に基づいて被験者を類型化する。次に4章では各グルー プの被験者の経路選択特性や興味を引かれた場所の特徴を検討した
上で、両者の関連を考察する。最後に5章では各グループの被験者の 個人特性、並びに経路選択の方略を検討し、異なる選択行動を示す 被験者はどのような個人特性を持つのかをまとめた結果を報告する。

\section{2. 経路選択実験}

\section{1 対象地図の選定}

実験に使用する地図は、様々な都市における街歩きを題材にした TV 番組『世界ふれあい街歩き』注1) で取り挙げられた街（サンプル 数：350）から選定することとした。上述した 350 枚の地図を 15 名 の被験者に呈示し、類似した街路パターンの地図をまとめて幾つか のグループに分類する作業を各自に行わせた。同じグループに分類 された地図同士に得点 1 を与える行列を作成し、15名分の行列を 重ね合わせることにより、類似度行列を作成した。このデータにク ラスター分析（最遠隣法）を適用することにより、11 のクラスター に分類した。

クラスター分析の結果と各クラスターの特徴を Table 1 に示す。各 クラスターからその特徵を最もよく表していると考えられる地図を 1 枚ずつ選定した。その際は、地域の多様性も考慮したが、周囲が 海に囲まれているものや河川・線路など街路に注目寸る際に影響を 及ぼす要素が含まれる地図については選定対象から除外した。

対象とする地図注 2) 注 3$)$ を Fig.1 に示す。また、対象地図の範囲は、 様々な公式観光サイトや街歩きマップなどで紹介されている 80 の 散策コースのエリアの平均面積を算出して、約 $1.0 \mathrm{~km}^{2}$ に設定した。 また、縮尺は実験に用いる A4 用紙に全体が収まるように約 1/6,000 に設定した。

\section{2 対象地図の街路特性}

対象地図の街路特性に関する指標を整理した 結果を Table 2 に示す。本研究では街路全体に関 する総単位街路数、総単位街路長、AL 格子度 (Grid Axiality) と、単位街路に関して、長さ、 幅員、Int.V（Integration Value）、湾曲度を対象 地図の街路特性の指標として採用した。なお、 単位街路は交差点の中心から他の交差点の中心 までの街路として定義する。

ここで、 $\mathrm{AL}$ 格子度注 4) は、街路網構成の変形

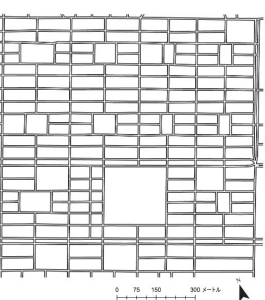

1 Savannah

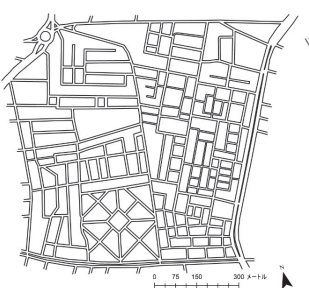

7 Fes

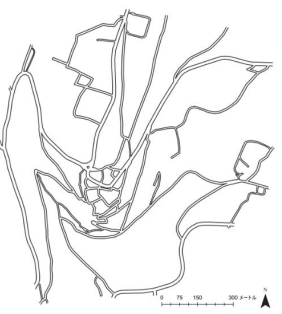

2 Gordes

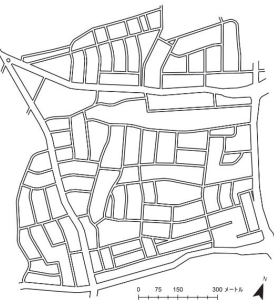

8 Arequipa

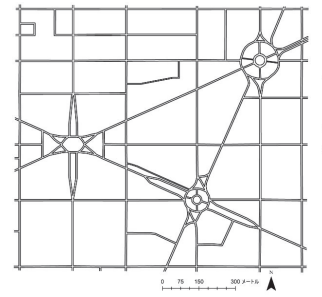

3 Washington

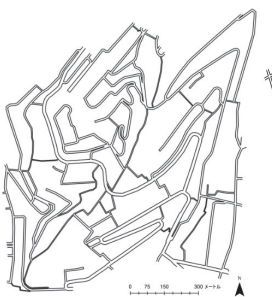

9 Genova

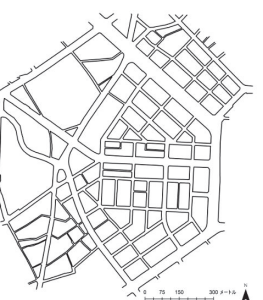

4 Fukuoka

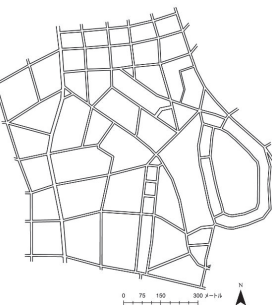

10 Qingdao

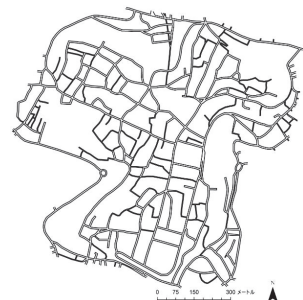

5 Perugia

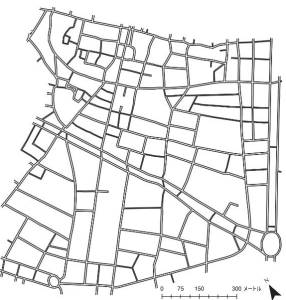

11 Barcelona

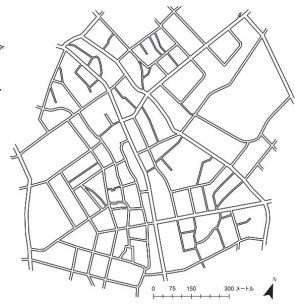

6 Lugang

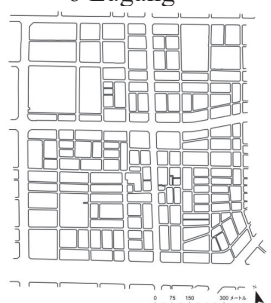

12 Hiroshima 
Table2 Street characteristics of the maps

\begin{tabular}{|c|c|c|c|c|c|c|c|c|c|c|c|}
\hline \multirow[b]{2}{*}{ Maps } & \multirow[b]{2}{*}{$\begin{array}{l}\text { Total number } \\
\text { of street units }\end{array}$} & \multirow[b]{2}{*}{$\begin{array}{l}\text { Total length of } \\
\text { street units }(\mathrm{m})\end{array}$} & \multirow[b]{2}{*}{\begin{tabular}{|c|} 
Grid \\
Axiality
\end{tabular}} & \multicolumn{4}{|c|}{ Length of a street unit $(\mathrm{m})$ Width of a street unit $(\mathrm{m})$} & \multicolumn{2}{|c|}{ Int. $V$ of a street unit } & \multicolumn{2}{|c|}{ Curvature of a street unit } \\
\hline & & & & Average & $\begin{array}{r}\text { Standard } \\
\text { deviation }\end{array}$ & Average & $\begin{array}{c}\text { Standard } \\
\text { deviation }\end{array}$ & Average & $\begin{array}{r}\text { Standard } \\
\text { deviation }\end{array}$ & Average & $\begin{array}{c}\text { Standard } \\
\text { deviation }\end{array}$ \\
\hline 1 Savannah & 432 & 29871.98 & 0.33 & 69.15 & 37.34 & 5.82 & 0.27 & 4.06 & 0.98 & 1.05 & 0.22 \\
\hline 2 Gordes & 100 & 13981.06 & 0.09 & 139.81 & 188.61 & 8.47 & 2.67 & 2.07 & 0.68 & 2.17 & 1.26 \\
\hline $3 \mathrm{~W}$ ashington & 192 & 20839.40 & 0.17 & 108.54 & 80.44 & 5.73 & 0.70 & 2.88 & 0.75 & 1.32 & 0.51 \\
\hline 4 Fukuoka & 219 & 16507.92 & 0.23 & 75.38 & 46.01 & 13.22 & 9.62 & 3.31 & 0.72 & 1.21 & 0.42 \\
\hline 5 P erugia & 384 & 25134.64 & 0.06 & 65.46 & 53.24 & 5.03 & 1.21 & 2.34 & 0.85 & 1.65 & 0.89 \\
\hline 6 Lugang & 229 & 19348.73 & 0.13 & 84.49 & 62.97 & 8.13 & 2.64 & 2.85 & 0.82 & 1.28 & 0.53 \\
\hline $7 \mathrm{Fes}$ & 465 & 25518.90 & 0.16 & 54.88 & 48.86 & 7.42 & 1.92 & 3.32 & 1.03 & 1.08 & 0.27 \\
\hline 8Arequipa & 251 & 20164.56 & 0.15 & 80.34 & 53.84 & 10.30 & 6.27 & 2.92 & 0.89 & 1.19 & 0.43 \\
\hline 9 Genova & 138 & 20726.57 & 0.07 & 150.19 & 135.79 & 7.97 & 2.95 & 1.92 & 0.55 & 2.18 & 1.55 \\
\hline 10 Qingdao & 135 & 15342.92 & 0.20 & 113.65 & 87.05 & 8.15 & 1.37 & 2.75 & 0.58 & 1.20 & 0.74 \\
\hline 11 Barcelona & 345 & 24991.37 & 0.12 & 72.44 & 46.02 & 5.35 & 1.13 & 3.09 & 0.86 & 1.19 & 0.46 \\
\hline 12 Hiroshima & 405 & 27720.98 & 0.29 & 68.45 & 40.23 & 12.41 & 13.58 & 3.82 & 1.03 & 1.02 & 0.14 \\
\hline
\end{tabular}

程度を表す指標值であり、值が低い 0 に

近いと不整形な街区構成であることを 示す ${ }^{8)}$ 。また、Int.V は SS 理論注5) にお ける最も重要な指標であり、街路構造の 特性を示す ${ }^{9)}$ 。Int. ${ }^{\text {注6) が高いと他の空 }}$ 間からのアクセスが容易であり、Int.V が低いと奥まった空間であり他の空間 からのアクセスが容易でないとされて いる。湾曲度注 7) は単位街路が直線的か 蛇行しているかの程度を示し、值が高く なるほど蛇行している程度が高くなる。

対象地図の街路特性をみるなら、地図 1 や 12 は総単位街路数と総単位街路長、

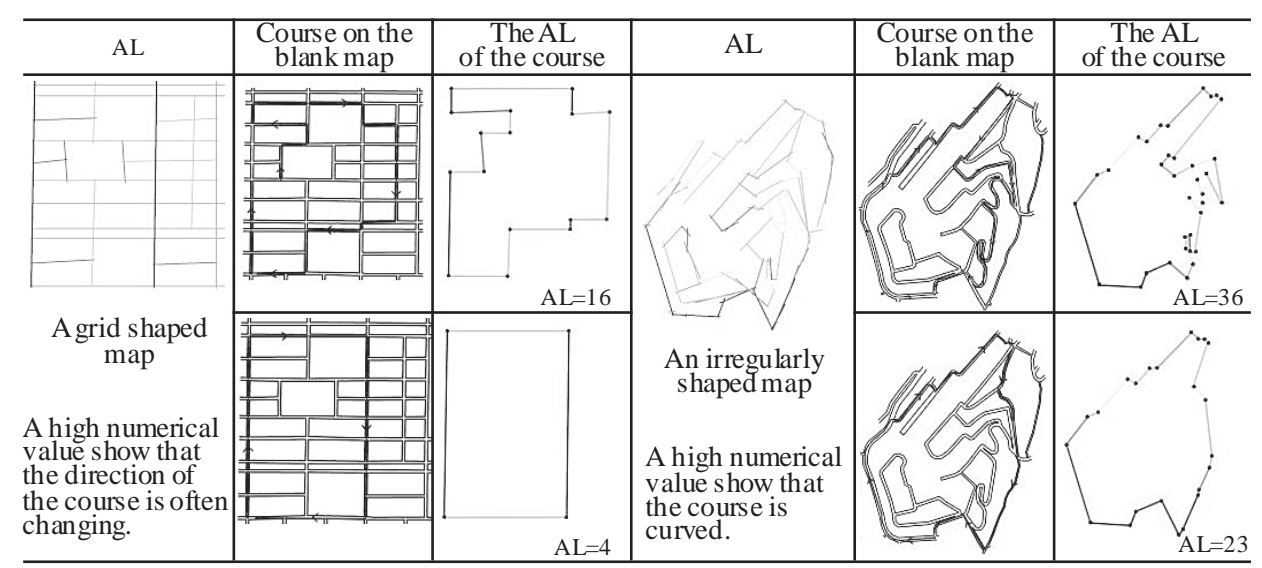
$\mathrm{AL}$ 格子度が高い值を示す一方、平均単位街路 Int.V の值が高く湾 曲度が低いため、多くの街路を有しており、格子状の街路網で構成 され、特に街路の形状は直線的で、街路同士のつながりが強い傾向 がみられる。これに対し、地図 2 や 9 などはこれとは逆の傾向を示 す。地図 4 や $8 、 12$ などは平均単位街路幅員が大きく標準偏差も大 きくなっており、Fig.1 に示したように地図の中で目立つ広い街路 のあることがわかる。地図 5 や7、11 などは平均単位街路長が短く 標準偏差も低く、細かい道で構成されている。また、地図 6 や 10 はいずれの指標も平均的な值をとっており、街路の観点からみると 比較的特徴のない地図であると考えられる。

\section{3 実験方法}

本研究では、個人特性と経路選択との関係をより明確に把握する ため、被験者には自由散策的行動を想定させた注8)。実験の手順に ついては、A4 の用紙に対象地図を 1 枚呈示し、(1)その地図の範囲内 で想定した散策経路を計画して地図上に描線する、(2)次に、経路を 描いた際に興味を引かれた行ってみたいと思った場所を線で囲む、 (3)最後に自分が計画した経路でその街を実際に散策してみたいと思 うかを評価する、という手順で、これら (1)〜 (3)を12 枚の各地図に 対して行わせた。

経路の描き始め・描き終わりとなる始点・終点は同じ位置で、外 縁部にランダムに配置し、また、地図の提示順序も被験者ごとにラ ンダムにした。同一の被験者でも、ある地図に対して常に同じ散策 経路を選択するとは限らないことから、実験は 3 回実施し、経路の 選択に偏りが出ないよう、各回それぞれ異なる始点・終点を指定し た。なお、散策や地図に対する意識や行動に関するフェイスシート

Table4 The relation between the indices of course selected

\begin{tabular}{c|c|c|c|c|c|c|c}
\hline \multicolumn{2}{c|}{} & \multicolumn{3}{|c|}{ Whole course } & \multicolumn{3}{c}{ Street unit } \\
\cline { 2 - 8 } \multicolumn{2}{c|}{} & $\begin{array}{c}\text { Number of } \\
\text { selected } \\
\text { street units }\end{array}$ & $\begin{array}{c}\text { Length } \\
\text { of course } \\
(\mathrm{m})\end{array}$ & $\begin{array}{c}\text { Tortuous } \\
\text { extent of } \\
\text { course }\end{array}$ & $\begin{array}{c}\text { Length of } \\
\text { street } \\
\text { units }(\mathrm{m})\end{array}$ & $\begin{array}{c}\text { Width of } \\
\text { street } \\
\text { units }(\mathrm{m})\end{array}$ & $\begin{array}{c}\text { Int.V of } \\
\text { street } \\
\text { units }\end{array}$ \\
\hline \multirow{2}{*}{$\begin{array}{c}\text { Whole } \\
\text { course }\end{array}$} & Length of course & $0.668^{* *}$ & & & & & \\
\hline & Tortuous extent of course & $0.518^{* *}$ & $0.723^{* *}$ & & & & \\
\hline \multirow{4}{*}{$\begin{array}{c}\text { Street } \\
\text { unit }\end{array}$} & Length of street units & $-0.461^{* *}$ & $0.262^{* *}$ & $0.186^{* *}$ & & & \\
\cline { 2 - 9 } & Width of street units (m) & $-0.130^{* *}$ & -0.058 & $-0.391^{* *}$ & 0.046 & & \\
\cline { 2 - 9 } & Int.V of street units & $0.330^{* *}$ & $-0.145^{* *}$ & $-0.523^{* *}$ & $-0.625^{* *}$ & $0.419^{* *}$ & \\
\cline { 2 - 9 } & Curvature of street units & $-0.323^{* *}$ & $0.246^{* *}$ & $0.488^{* *}$ & $0.748^{* * *}$ & $-0.214^{* *}$ & $-0.814^{* *}$ \\
\hline
\end{tabular}

\begin{tabular}{|l|l|l|l|}
\hline $\pm 0.00 \sim \pm 0.20$ & $\pm 0.20 \sim \pm 0.40$ & $\pm 0.40 \sim \pm 0.70$ & $\pm 0.70 \sim \pm 1.00$ \\
\hline
\end{tabular}

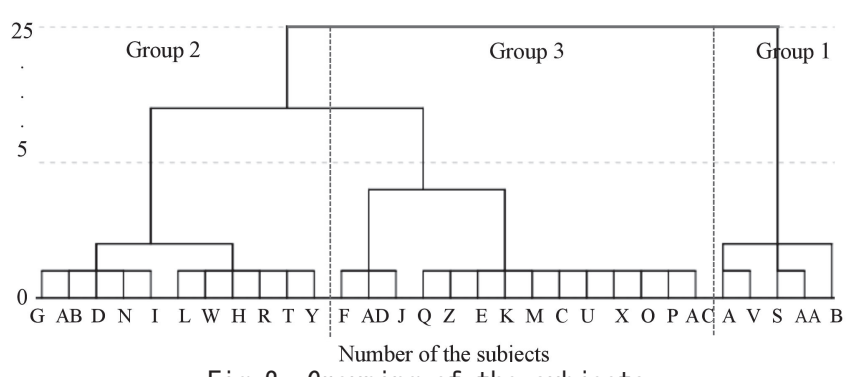

Fig. 2 Grouping of the subjects

への回答は 3 回目の実験終了時に求めた。本研究においては散策を 散歩や街歩きなど特に目的を持たずに街をぶらぶら歩くこととした。

\section{3. 経路選択結果に基づく被験者の類型化}

3. 1 経路選択に関する指標

被験者の経路選択特性を表す指標として、選択された経路全体に 

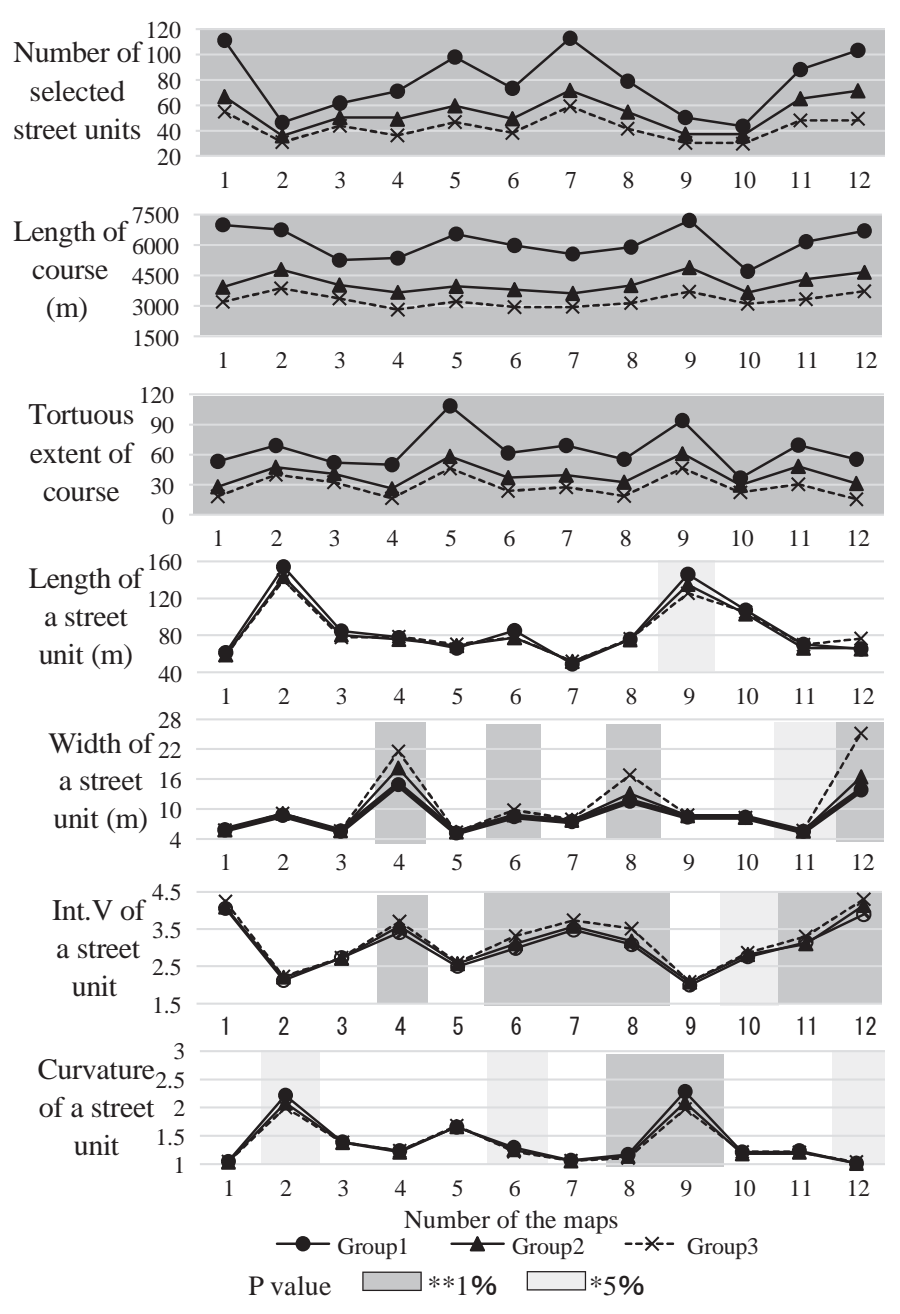

Fig. 3 The tendency of course selected in each map

関する選択単位街路数、散策経路長、転回頻度の 3 指標之、選択経 路に含まれる単位街路の長さ、幅員、Int.V、湾曲度の 4 指標を検討 の対象とした。

なお、転回頻度とは、散策をする際に前進方向を变更する傾向を 表す指標值であり、被験者の選択経路を地図の $\mathrm{AL}$ と重放合わせた 際、選択経路に含まれる AL の数を示す。計算例を Table 3 に示す。

\section{2 被験者の類型化方法と結果}

次に上述した7指標を用いてクラスター分析によって被験者の類 型化を図ったが、その際、なるべく独立性の高い指標を用いるため、 12 枚の地図における被験者 30 人の 3 回の実験データ 1080 個をサンプ ルとして、各指標間の相関分析を行った。結果をTable 4に示す。こ れより、相互に高い相関を示す指標の一方を除外した注9)

以上より、独立性が高いと考えられる 4 指標（選択単位街路数、 転回頻度、単位街路 Int.V、単位街路幅員) を選択し、標準化したデ ータにクラスター分析（ウォード法）を適用した。30人の被験者を 3 クラスターに分類した結果を Fig.2 に示す。

\section{4. グループ別選択結果の特徵}

\section{1 選択経路の特性}

各グループの散策傾向を表すため、経路選択に関わる 7 指標それ ぞれの平均值をグループ別に集計した結果、並びに、グループ間の 分散分析の結果を 12 枚の地図ごとに Fig.3 に示す。各グループに属
する被験者の特性について比較して考察する。

選択経路全体に関寸る選択単位街路数、散策経路長、転回頻度に ついてみると、 3 グループ間で比較的大きな差がみられる。

グループ 1 は 3 指標全てでいずれの地図においても最も高い值を とっており、これらの被験者は、各地図の街路特性の違いにかかわ らず、長い距離を計画し、多くの道を通過し、前進方向をよく変更 する傾向にあるといえる。これに対してグループ 3 はグループ 1 と 逆の傾向を示し、3 指標全てで最も低い值をとっている。このグル 一プの被験者の経路は短めで、通過する単位街路数も多くはなく、 あまり方向を変更しない傾向にある。グループ 2 は両グループの中 間的な傾向が認められるが、グループ 3 により近いといえる。

また、選択された単位街路に関する指標についてみるなら、まず、 単位街路長をみると、グループ間にあまり有意な差は認められない。 地図 9 ではグループ 1 が長い単位街路を選択する傾向にある。

次に、幅員については、地図 4、6、8 や 12 などでグループ間に差 がみられる。Table 2 より、これらの地図では単位街路幅員の偏差が 大きく、非常に広い幅員の街路が存在しており、街路幅員の違いが 目立つため、各グループの選択結果にも大きな差が生じたと考えら れる。グループ 1 は低い值をとり、狭い道を選択しやすいのに対し て、グループ 3 は最も高い值をとり、広幅員の街路を好むと考えら れる。

単位街路 Int.V についても、地図 4、7、8 や 12 などでグループ間 に差がみられる。これらの地図の単位街路 Int.V は比較的高く、特 に地図 7 や 12 では標準偏差も大きい。グループ 1 は最も Int.V の低 い街路を選択し、他のグループに比べ入り組んだ道を選択しやすい のに対し、グループ 3 は最も Int.V の高い街路を選択し、分かりや すい大通りを好むと考えられる。

単位街路湾曲度についてみるなら、地図 2 や $9 、 12$ などでグルー プ間の差がみられる。地図 2 や 9 の単位街路湾曲度と標準偏差の值 は共に高く、比較的直線的な街路がある一方、非常に曲がりくねつ た街路もあるため、グループ間に選択結果の差が生じたと考えられ る。また、地図 12 では右下の部分に幾つか曲線的な街路があり、他 の直線的街路と違って目立つため、グループ間の選択結果にも差が 生じたと考えられる。グループ 1 は高い湾曲度をとり、曲線的な街 路を選択寸るのに対し、グループ 3 は湾曲度が低く、直線的なわか りやすい街路を選択する傾向にある。

\section{2 誘引空間の特性}

異なる被験者に好まれた街路の特徴をさらに把握するために、散 策経路における街路以外に、被験者に指摘された興味が引かれた、 行ってみたい場所（以下、誘引空間）の特徴について考察する。

グループ別の誘引空間の分布を、一部の地図について Fig.4 に示 す。異なるグループの被験者であっても、指摘された誘引空間は共 に特徵的な場所に集中寸る傾向がみられる注 10)。しかしながら、グ ループ間の違いをより詳細に検討するため、誘引空間の面積、並び に、誘引空間に含まれる単位街路の各指標について、グループごと の平均值を求めた。分散分析の結果と併せて Fig.5 に示す。

全体的にグループ間で大きな違いはみられないが、指摘面積につ いては、ほとんどの地図でグループ1の值が最も高く、これらの被 験者は散策の計画をする際に興味を持った場所や気になった場所を 相対的に多く、あるいは、広く指摘するものと考えられる。これに 
対してグループ 3 では指摘面積が最も小さく、これらの被験者は街 路形状とパターンのみを示寸白地図からは興味のある場所を指摘し にくいか、またはピンポイントで指摘する傾向があるものと考えら れる。誘引空間に含まれる単位街路数についても同様の傾向がみら れる。

誘引空間に含まれる単位街路に関する 4 指標についてみるなら、 単位街路長では、地図 7 や $10 、 12$ でグループ 3 の值が最も高いが、

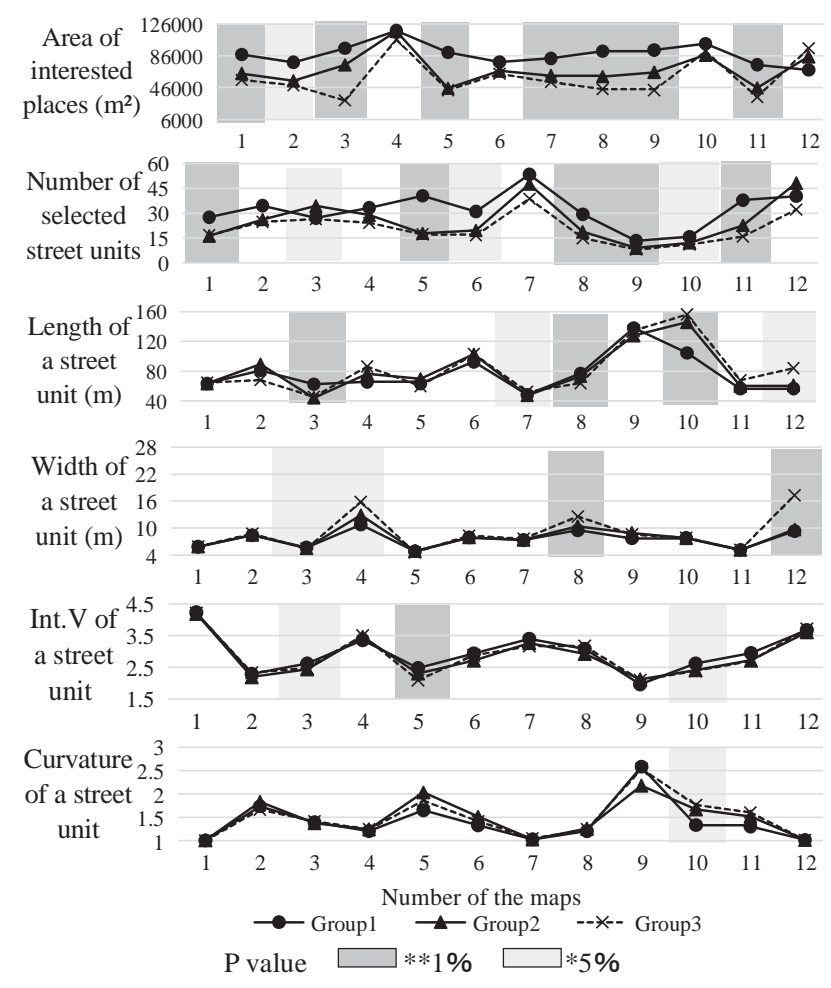

Fig. 5 The characteristics of inetrested places in each map
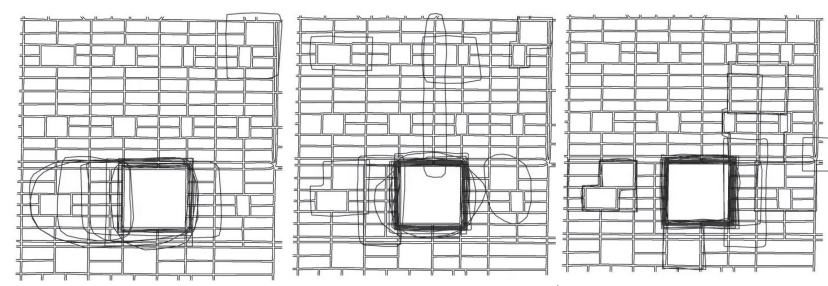

1 Savannah (Group1, 2, 3)
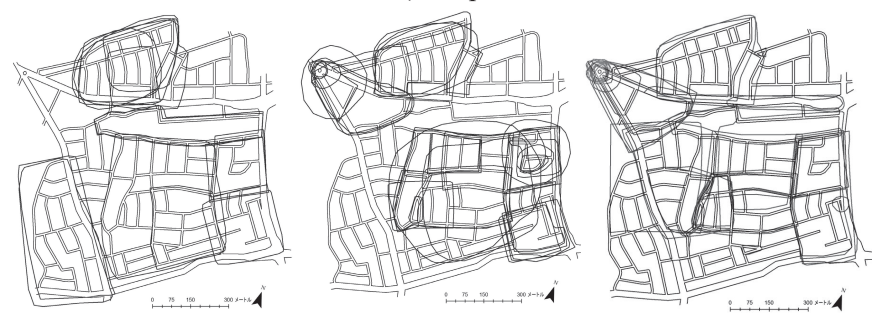

8 Arequipa(Group1, 2, 3)
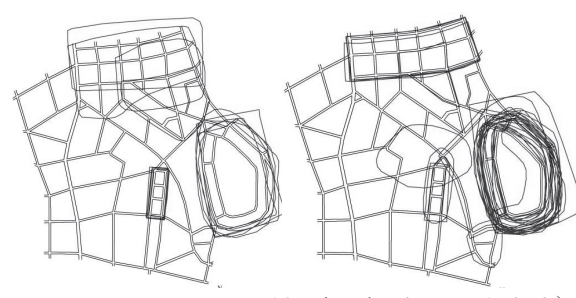

10 Qingdao(Group1, 2, 3)

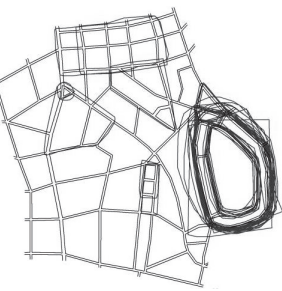

地図 3 や 8 ではグループ 1 の值が最も高く、各グループの指摘に各 地図に共通した傾向はみられない。

一方、単位街路幅員をみるなら、地図 $4 、 8$ や 12 などでグループ 間に有意差がみられ、グループ 3 の幅員の值は他のグループより広 く、これらの被験者は誘引空間においても広幅員の街路に惹かれや 寸い傾向があるものと考えられる。

単位街路 Int.V についてみるなら、グループ間で有意差のある地 図 3、5、10 では、グループ 1 に比べ、グループ 2、3 の Int.V の值 が低く、選択経路における各グループの特徴と逆の傾向がみられる。 グループ 3 は他のグループに比べ、興味をもった場所はわかりにく い場所になるものの、実際に経路を計画する際には他のグループよ り分かりやすい街路を通る傾向があることから、散策をする際の空 間を把握する能力などが影響しているものと推測される。

これより、選択された街路と誘引空間に含まれる街路は共に被験 者に好まれた街路と考えられるが、グループ別に両者の特徵に違い がみられる場合もある。その原因としては、誘引空間は興味を惹か れた街路として指摘され、単純に被験者の好みを表すと考えられる のに対し、選択経路は歩いてみたい街路として選択され、興味や好 み以外に他の個人特性の影響も受けていると推測される。次に、経 路選択と個人特性との関係を考察する。

\section{5. グループ別個人特性と経路選択方略 \\ 5. 1 グループ別個人特性 \\ 5. 1 . 1 個人特性}

被験者の散策や地図に対する意識や行動について尋ねたフェイス シートの質問項目に対する 4 段階尺度の回答に 1 から 4 の得点を付 与し、主因子法、バリマックス回転による因子分析を適用した結果 を Table 5 に示す。固有值 1.0 以上の条件により、 5 因子が抽出され
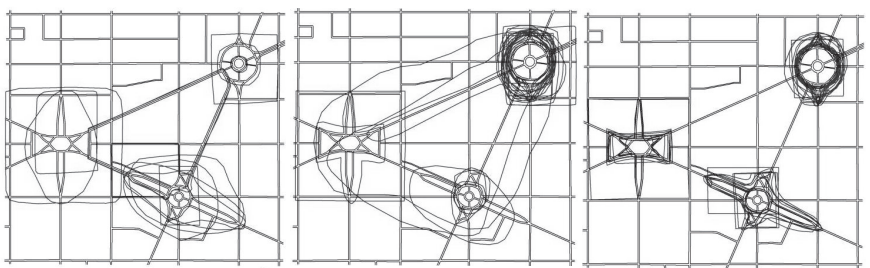

3 Washington (Group1, 2, 3)
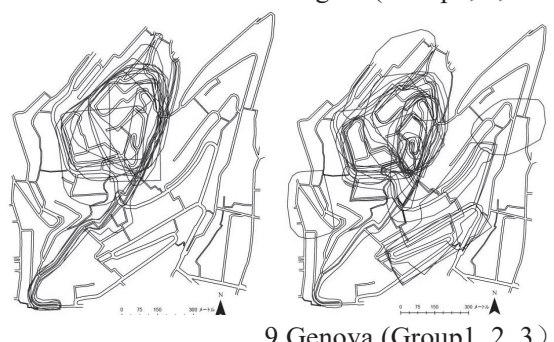

9 Genova (Group1, 2, 3)

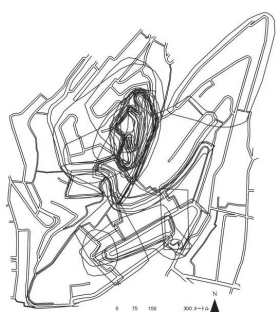

Fig. 4 Distribution of interested places in each group

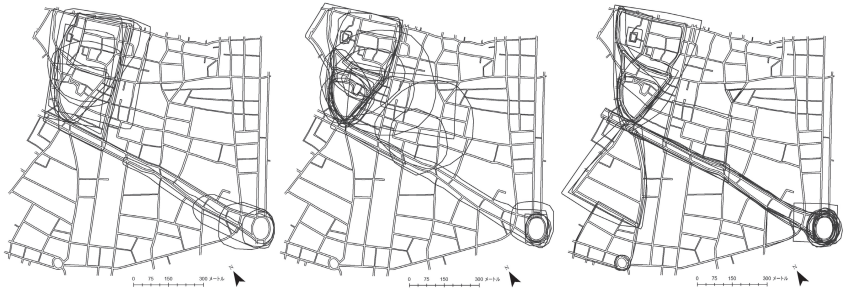

11 Barcelona(Group1, 2, 3) 
Table5 Result of factor analysis

\begin{tabular}{|c|c|c|c|c|c|c|}
\hline No. & Items & $\begin{array}{c}\text { Space } \\
\text { recognition }\end{array}$ & $\begin{array}{l}\text { Interest in } \\
\text { stroll ling }\end{array}$ & $\begin{array}{l}\text { Interest } \\
\text { in maps }\end{array}$ & $\begin{array}{l}\text { Sense of } \\
\text { direction }\end{array}$ & Curio \\
\hline 12 & You seldom get lost. & 0.82 & 0.113 & -0.02 & 0.175 & -0.268 \\
\hline 5 & $\begin{array}{l}\text { You can reach the d } \\
\text { without a map. }\end{array}$ & 0.713 & 0.032 & 0.186 & 0.044 & -0.14 \\
\hline 6 & \begin{tabular}{|l} 
You can grasp \\
quickly on a map.
\end{tabular} & 0.712 & -0.131 & 0.1 & 0.512 & 0.2 \\
\hline 4 & $\begin{array}{l}\text { You can find your residence } \\
\text { on a map. }\end{array}$ & 0.694 & -0.291 & 0.168 & -0.137 & 0.3 \\
\hline 15 & You al ways leisurely action. & -0.158 & 80 & -0.066 & -0.018 & 0.031 \\
\hline 8 & You like stroll ing. & 0.12 & 0.706 & 0.296 & 0.316 & 0.038 \\
\hline 14 & $\begin{array}{l}\text { You want to be outdoors When } \\
\text { time is free. }\end{array}$ & -0.062 & 0.488 & 0.267 & -0.104 & 0.043 \\
\hline 1 & $\begin{array}{l}\text { You can imagine the place when } \\
\text { you read a map. }\end{array}$ & 0.26 & 0.33 & .644 & 0.067 & -0.057 \\
\hline 11 & $\begin{array}{l}\text { y to see th } \\
\text { ding scener }\end{array}$ & -0.004 & -0.047 & 0.607 & 0.101 & 0.075 \\
\hline 2 & \begin{tabular}{|l|}
$\begin{array}{l}\text { You are interested in shape of the } \\
\text { street. }\end{array}$ \\
\end{tabular} & 0.323 & 0.268 & 0.56 & 0.173 & -0.14 \\
\hline 7 & $\begin{array}{l}\text { You can tell the direction without } \\
\text { using a map. }\end{array}$ & 0.184 & 0.002 & 0.175 & 0.805 & -0.176 \\
\hline 10 & \begin{tabular}{|l} 
You \\
ther
\end{tabular} & -0.066 & 0.229 & 0.366 & -0.123 & 0.688 \\
\hline 3 & $\begin{array}{l}\text { You are interested in rare place } \\
\text { name. }\end{array}$ & 0.165 & 43 & -0.032 & -0.244 & 0.452 \\
\hline 9 & $\begin{array}{l}\text { You want to walk the streets which } \\
\text { you do notknow. }\end{array}$ & -0.323 & 0.193 & 0.258 & 0.293 & 0.362 \\
\hline 13 & $\begin{array}{l}\text { You prefer traveling alone } \\
\text { traveling with others. }\end{array}$ & 0.049 & 0.069 & 0.162 & 0.002 & -0.352 \\
\hline
\end{tabular}

た。因子負荷量の高い項目から各因子の意味内容を考えるなら、第 1 因子は自分の居る場所を把握できるか否かを示す『認知能力』、 第 2 因子は散策を好むか否かを示す『散策への関心』、第 3 因子は 街路の形状一の興味や地図を見て場所を想像するか否かに関する 『地図への関心』、第 4 因子は地図を見ずに方角がわかるか否かを 示す『方向感覚』、第 5 因子は未知の事物への興味を示す『好奇心』 とそれぞれ解釈できる。

各グループの個人特性を検討するため、各因子の平均因子得点を グループごとに求めた結果を Fig.6 に示す。まず、グループ 1 は 3 グループの中で『散策への関心』が最も高く、『認知能力』と『方 向感覚』は中庸で、『地図への関心』と『好奇心』は最も低くなっ ている。これより、このグループの被験者は他のグループより散策 を好み、ある程度の空間を把握寸る能力を有してはいるものの、地 図を見ることや場所の想像に対する好奇心には乏しいと考えられる。 グループ 2 は、『散策への関心』がグループ 1 より低いが、他の 因子得点は 3 グループの中で最も高く、空間を把握する能力が高く、 比較的外出を好むと考えられる。グループ 3 は『散策への関心』や 『認知能力』『方向感覚』が他のグループより低く、空間を把握す る能力と散策への興味が共に乏しいと考えられる。

\section{1. 2 散策意欲}

さらに、計画した経路を実際に通りたいか否かについての意欲に 対する 4 段階尺度の回答に 1 (通りたくない側) から 4 (通りたい側) の得点を付与し、グループごとに平均評価得点を求めた。結果を Fig.7 に示す。

全体の傾向をみるなら、3グループ間に有意な差はあまり認めら れないが、地図 5 や $6 、 8$ ではグループ間に有意差がみられる。これ らの地図に共通してグループ 1 と 2 の得点は近く、グループ 3 の得 点は非常に低い。したがって、これらの地図に対してグループ 3 は 計画した経路を実際に通りたい意欲が他のグループより低く、あま り計画通りに散策したくないものと考えられる。

Table 2 をみると、地図 5 の AL 格子度は最も低く、複雑な街路パ ターンを有していると言え、且つ単位街路数の值が高く、多くの細 かい街路で構成されており、認知能力の低いグループ 3 にとって、 実際に歩くのは負担になると考えられる。一方、地図 5 と同様に $\mathrm{AL}$

\begin{tabular}{|c|c|c|c|c|}
\hline \multirow{2}{*}{ 個人特性 } & \multirow{2}{*}{ Personal features } & Low $\leftarrow$ & \multicolumn{2}{|c|}{$\rightarrow$ High } \\
\hline & & $\begin{array}{ll}-0.6 & -0.2 \\
\end{array}$ & 0.2 & 0.6 \\
\hline 認知能力 & Space recognition & & 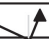 & \\
\hline 散策への関心 & Interest in strolling & & & \\
\hline 地図への関心 & Interest in maps & $<$ & & \\
\hline 方向感覚 & Sense of direction & $x=$ & 4 & \\
\hline 好奇心 & Curiosity & 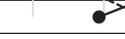 & & \\
\hline
\end{tabular}

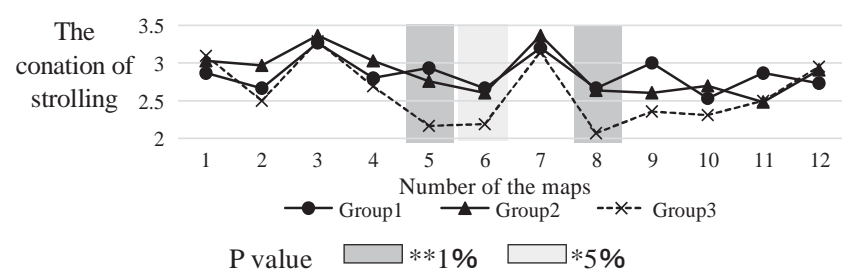

Fig. 7 The conation of strolling in each map 格子度が低い地図 2 や 9 は、単位街路数が地図 5 に比べて少なく、 また単位街路の湾曲度が非常に高いことから、普段あまり目にしな い街路パターンと言える。そのため、グループ 3 の興味を引いたと 考えられ、結果として、地図 2 と 9 に対するグループ 3 の散策意欲 が地図 5 より高くなり、他グループとの差も小さくなったと推察さ れる。

また地図 6、8および 11 は、ほぼ同程度の AL 格子度であるにも 関わらず、散策意欲の平均評価点を見ると、地図 $6 、 8$ はグループ 3 の值が低いのに対して、地図 11 はグループ 3 の值が高く、グループ 2 と同程度となっている。誘引空間の分布図（Fig.4）を見ると、地 図 11 は、地図の右下の円形街路から左上の湾曲街路が集まるエリア に誘引空間が集中していることから、被験者の興味をひき、グルー プ 3 の散策意欲が高くなったものと推察される。それに対し、地図 6、8 では、誘引空間が比較的分散していることから、被験者の興味 をひく特徵がそしく、散策への関心の低いグループ 3 の散策意欲を 喚起しにくいと推察される。

\section{2 グループ別経路選択方略}

被験者が地図上で散策経路を計画する際にどのような考えや理由 に基づいて決定したのかを 3 回の実験各回に自由記述形式で回答さ せた。各カテゴリーに該当する各グループの回答数をそれぞれの被 験者数で基準化し、1 人あたり指摘回数を求めた。散策したい側の 理由を Fig.8、散策したくない側の理由を Fig.9 に示す。

\section{2. 1 共通した傾向}

3 グループに共通した傾向をみるなら、散策したい側の理由は多 く、グループごとに大きな違いがあるのに対して、散策したくない 側の理由の指摘数は少ないことがわかる。

また、散策したい側の理由の中には、街路の幅員や形状など全て のグループの被験者が指摘しているもののあることがわかる。散策 したくない側の理由では、「一度通った道」注 ${ }^{11)} の$ 指摘数が比較的 多く、被験者は散策経路を選択する際、既に歩いた街路を再度通る のは面白味に欠けるため、なるべく未知の街路において経路を構成 しようとする傾向があるものと考えられる。

\subsection{2 グループ間の比較}

散策したい側の理由をみると、街路の幅員については、グループ 3 は「1.大通り」の指摘数が他のグループより多いのに対し、グルー プ 1 は「2.小道」の指摘数が多く、グループ 3 はグループ 1 より分 かりやすい簡単な道を通りたい者が多いと考えられる。 


\begin{tabular}{|c|c|c|c|}
\hline Keywords & Items & 0 & 3 \\
\hline 1 Main street & Wide streets & 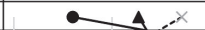 & \\
\hline 2 Path & Narrow road or alley & -1 & $\longrightarrow$ \\
\hline 3 Shape & A street of special shape & $-x$ & \\
\hline 4 Curve & A very winding road & 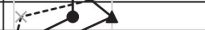 & \\
\hline 5 Far & A place far from the starting point & $\dot{\alpha}$ & \\
\hline 6 Near & A place near the starting point & 0 & \\
\hline 7 Imagine & It looks like a built-up area & & \\
\hline 8 Interest & The areas where I am interested in & 4 & \\
\hline 9 Complex & Complicated place & & 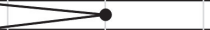 \\
\hline 10 Simple & A simple street or tidy street & & \\
\hline 11 Roughly & Walk roughly in the area & & $\rightarrow-$ Group 1 \\
\hline 12 Various & All kinds of streets, lots of places & 4 & $\neg$ Group2 \\
\hline 13 Other & Walk in a clockwise direction, go left at the crossing in the road, etc. & & $--x-$ Group3 \\
\hline
\end{tabular}

Fig. 8 Course selected strategy of each group (Positive)

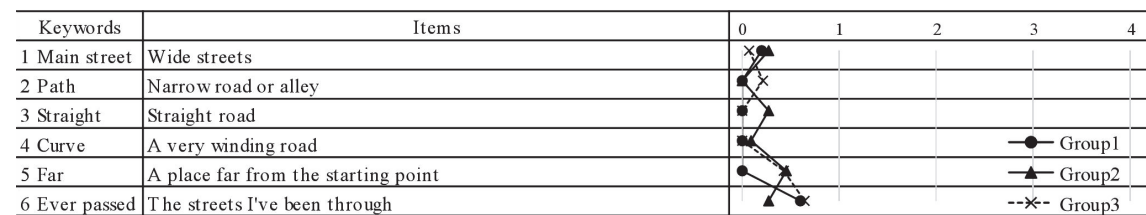

Fig. 9 Course selected strategy of each group (Negative)
Table6 The relationship among selected, personal feature and strategy

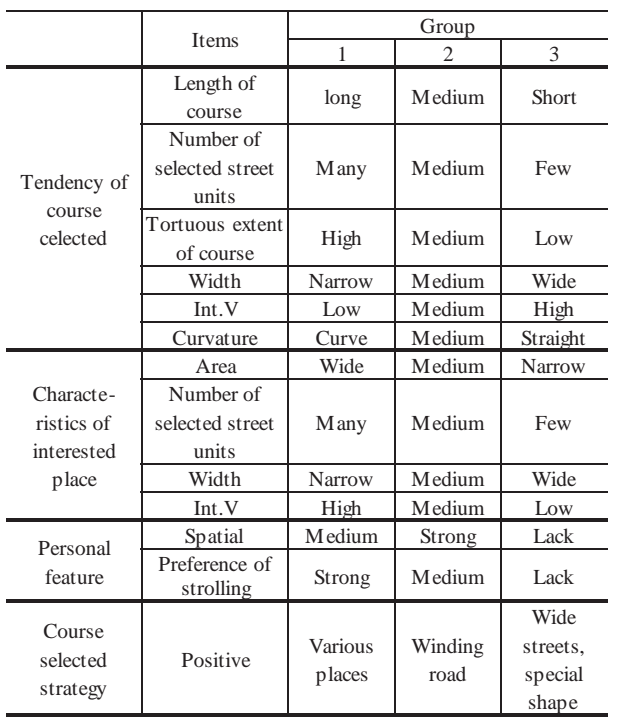

高い空間認知能力と強い好奇心の影響を受けていると推測される。

グループ 3 は散策経路が短く、分かりやすい街路を選択し、低い 空間把握の能力の影響を受ける一方、他のグループより特徴的な街 路を誘引空間として指摘しており、これらの被験者は散策への関心 が低いため、特徵的な場所しか興味が惹かれないものと推測される。 また、経路選択方略についても、分かりやすい大通りや特徴的な場 所に着目して経路を計画する傾向がみられる。

\section{6.おわりに}

本研究では、様々な都市の街路パターンを対象として白地図を用 いた地図記入法による経路選択実験を行い、経路選択結果に基づい て被験者を類型化した。次に、各グループの被験者の経路選択傾向 を明らかにした。また、興味を引かれた場所の特徴をグループ別に 検討した上で、経路選択との関連を考察した。さらに、個人特性に 関する因子を抽出し、グループ別に被験者の個人特性の違いを把握 した。最後に、被験者の散策をする際の考えや計画の方略を踏まえ、 個人の行動、個人特性、考え方の相互関係について把握した。

経路選択行動を通して、個人の特性や行動の特性の一端を解明し たが、得られた知見が類似した街路パターンを有する都市における 人間行動の予測、さらにはその街路のレジビリティや魅力の向上を 図る方策検討にも活用し得ると期待している。また、経路選択行動 に関する研究に有意義な示唆をもたらし、人間の街路パターンに対 する捉え方や人間の行動を理解する面からも有用な情報が得られた ものと考えられる。

しかしながら、経路選択行動は独立している街路の特徴の影響を 受けるだけではなく、時間の経過につれて人々の空間的位置が変化 するシークエンスも大きな特徴であると考えられる。したがって、 今後は、個人の違いや経路選択行動をより詳細に解明するため、シ 一クエンスの観点から、移動することで徐々に変化していく空間的 位置や、既に体験した場所などの記憶の蓄積が経路選択に与える影 響について検討する予定である。

また、前述したように、人々は実際にどの程度、地図上で選択し た経路通りに行動するのかについては、異なる被験者によって、地 かりにくく、形状も珍しいことから、これらの被験者の選択経路は 
図上の選択経路から乘離する度合いとその影響要因や考え方、地図 上の選択行動と実際の選択行動との特徵の違いなどを明らかにする 必要があるが、今後の課題としたい。

\section{謝辞}

本研究を展開するにあたっては、当時の広島大学工学部建築学科 の学生諸君に実験・調查を通して多くの協力を戴いた。記して、深 謝する。

\section{注}

注 1) NHK で 2005 年 3 月〜2015 年 9 月までに放送されたもの。本研究 では、歩行行動を対象としているため、歩行に適する都市の抽出を意 図し、当該番組に放送されたまちの中から対象地を選定することとし た。

注 2）本稿では、地図上での経路選択に着目しているが、将来的には白地図 上での経路選択行動と、実際に歩行した際の経路選択行動との対応を 調查することを意図しており、そのため広島市内の地図 (C12) も対象に 含めた。

注 3）実際の街路空間の歩行体験の有無は、選択結果に影響を与えると考え られる。そこで本研究では、まず、海外対象地の歩行経験を把握する ため、海外滞在経験の有無、海外滞在経験がある場合はその滞在国名、 都市名について記憶の範囲内で回答を求めた。その結果、被験者 30 名 中 18 名は海外滞在経験があったが、その滞在先としては、フランス(パ リ）やアメリカ（ニューヨーク）などであり、対象都市の回答は見ら れなかった。次に、国内対象地の歩行経験を把握するため、出身地の 回答を求めた。その結果、広島県出身の被験者がいたが、その出身地 は只市であり、日常的な行動圈に対象地は含まれていないものと推察 された。また、出身地以外の「これまでに訪れて印象に残っている場 所（国内）」を記憶の範囲内で回答を求めた結果、北海道や東京、京 都の回答が多く見られたが、対象地を挙げた被験者はみられなかった。 さらに、日常的に広島市内の歩行経験者を除くために、被験者を実験 時点で東広島市に居住していることを条件とし、日常的な行動圈に対 象地が含まれていないサンプルとした。以上のことから、本研究の被 験者は、少なくとも日常的な行動圈に対象地がなく、かつ実験では街 路構造のみを示した地図を利用しているため、本研究において歩行経 験の影響は小さいと考えた。

注 4) AL 格子度（Grid Axiality、以下 $\mathrm{Ga}$ ）は、直交グリッドの街区と比較し た場合の変形の程度を表し、值 0 から 1 の間で表され、1に近いほど変 形が少なく直交グリッドに近似しており、0 に近いほど不整形な街区構 成であることを示す。この値は以下の(式 1)より求められる。

$$
\mathrm{Ga}=(2 \sqrt{\mathrm{I}}+2) / \mathrm{L} \quad-(\text { 式 } 1)
$$

注 5) SS 理論は Bill Hillier らによって提唱された、空間の位相関係に着目し た空間解析手法であり、都市のオープン・スペース形態の定量分析に 用いられる。

注 6) Int.V は、最も長い視線・直線移動を表す軸線であるアクシャルライン （Axial Line 以下、AL）を基本単位とし、以下の（式 2）〜（式 4）上 り求められる。AL は SS 理論における基本的なコンセプトとし、一本 の $\mathrm{AL}$ は一本の街路空間を表す。

$\begin{array}{ll}\mathrm{RA}=2(\mathrm{MD}-1) /(\mathrm{k}-2) & - \text { (式 2) } \\ \text { RRA }=\text { RA/Dk } & \text {-(式 3) } \\ \text { Int.V=1/RRA } & \text {-(式 4) }\end{array}$

RA：域全体に対する相対的深さ
$\mathrm{MD}$ : 平均の深さ (Depth)
$\mathrm{k}: \mathrm{AL}$ の総数

RRA : RA を標準化した值

$D_{k}$ ：標準化に利用する值、 $D$ 值 5

式 2 において、深さ（Depth）はある空間から他の空間までに介在する 空間の数をいい、つながりの強さを表す。RA は対象とする地域全体か ら見た相対的な深さを表し、この值が大きいと対象とするエリアの中 でその空間は相対的に深く入り組んだところにあるとされる。式 3 に おいて、RRA は、エリアの規模の影響を取り除くためにRA を標準化 した值である。式 4 においては、Int.V はRRA を感覚的に分かりやすく するために逆数をとった值である。

注 7）単位街路の湾曲度とは、白地図を地図の $\mathrm{AL}$ と重祮合わせ、一本の単位 街路に含まれる $\mathrm{AL}$ の数を記録したものが当該単位街路の湾曲度にな る。

注 8）経路選択行動は、経路探索的行動と自由散策的行動に大別することが できる ${ }^{10)}$ 。経路探索的行動は目的地があらかじめ決まっており、その 場所に辿り着くことを優先して考えるために、選択行動は目的地まで の最短距離とわかりやすさの影響を強く受けるものと推察され、経路 選択の影響要因と寸る個人の特性は主に、空間把握に関する能力であ ると考えられる。しかし、地図上での経路選択の場合は、始点と目的 地の位置関係が直接的に把握できるため、個人の空間把握能力の違い が明確に選択行動に反映されない可能性がある。一方、自由散策にお いては歩行者は心の赴くままに経路の選択を行うと予想されるため、 経路探索的行動とは異なる特性の影響を強く受けるものと考えられる。 例えば、個人の好みや関心、考えなど空間把握能力以外に人間の持っ 特性である。自由散策的行動を想定させることによって、これらの特 性と経路選択との関係を明確に取り出し、より個人の違いを把握でき るのではないかと考え、本研究では自由散策的行動に着目することに する。

注 9）まず、散策経路長を、転回頻度や選択単位街路数との間に高い正の相 関がみられること、通過した単位街路数と当該単位街路の長さに基づ く指標であることから除外した。次に、単位街路湾曲度を、単位街路 長、単位街路 Int.V との間に高い相関がみられること、転回頻度と同様 にアクシャルラインで表すことができることから除外した。単位街路 長は単位街路 Int.V との間に高い相関がみられること、単位街路の形を 示す指標であることから除外した。

注 10)グループ 2、3の被験者に指摘された誘引空間はグループ 1 より集中し ているようにみえるが、各グループに属する被験者数が異なっており、 グループ 1(5 人) はグループ 2(11 人)やグループ 3(14人)上り少ないた め、指摘回数も少ないことに留意されたい。

注 11) 被験者が地図上でそれまでに描いた経路に含まれる街路を「一度通っ た道」とした。

\section{参考文献}

1) Tsukaguchi, H. and Matuda, K. : Analysis on Pedestrian Route Choice Behavior, Journal of JSCE, Vol.709, pp.117-126, 2002.7

塚口博司, 松田浩一郎: 歩行者の経路選択行動分析, 土木学会論文集, 第 709 号，pp.117-126，2002.7

2) Saito, H. Tanaka, T. Nishina, D. and Inachi,S. : Research on the Pedestrian Route Choice Behavier in Urban Space.: (Part 2) Analysis on the Relationship between Pedestrian Route Choice and its Environments/Space Images, Summaries of Technical Papers of Annual Meeting, Architectural Institute of Japan, F-I, pp.227-228, 2011

斎藤寛彰, 田中貴宏，西名大作，稲地秀介：都市空間における歩行者の 経路選択傾向に関する研究：その 2 経路選択頻度と物理的環境・街路空 間イメージとの関連分析, 日本建築学会大会学術講演梗概集, F-I, pp.227 $-228,2011$

3) Takeuchi, D. : A Study on Pedestrian's Preference in Route Selecting, Journal of JSCE, Vol.259, pp.91-101, 1977.3 竹内伝史：歩行者の経路選択性向に関する研究，土木学会論文報告集， 
第 259 号, pp.91-101, 1977.3

4) Miura, K. Sano, H. and Tanabe, K.: Pedestrian Path Choice and Wayfinding Behavior - A Study on the Eye Fixation in wayfinding in the Street Part 1 Journal of Architecture and Planning (Transactions of AIJ), No.569, pp.131-138, 2003.7

三浦金作，佐野浩史，田邊和義：歩行経路選択と探索行動一街路空間に おける探索歩行時の注視に関する研究 その 1 - , 日本建築学会計画系論 文集，第 569 号，pp.131-138，2003.7

5) Miura, K.: Eye Fixation Tendency of Pedsetrians Based on Different Walking Conditions-A Study on the Eye Fixation in Wayfinding in the Street Part4-, Journal of Architecture and Planning (Transactions of AIJ), No.624, pp.371-378, 2008.2

三浦金作 : 歩行条件の異なる歩行者の経路選択と探索行動についてー街 路空間における探索歩行時の注視に関する研究 その 4-, 日本建築学会 計画系論文集, 第 73 巻, 第 624 号, pp.371-378, 2008.2

6) Nishio, K. Zaino, H. Matubara, N and Kurazumi, Y.: Individual Difference Based on the Ability to Understand the Street Patterns - Astudy on the continuous recognltion of street space from the view point of individualdifferencePart Journal of Architecture, Planning and Environmental Engineering (Transactions of AIJ), No.540, pp.205-212, 2001.2

西應浩司，材野博司，松原斎樹，藏澄美仁：街路パターンを認知する能 力の個人差一街路空間の連続的認識における個人差その 1 , 日本建築学会 計画系論文集，第 540 号, pp.205-212，2001.2

7) Wakabayashi, Y.: The Role of Maps in the Cognition of Geographic Space, Cognitive Studies, 15(1), pp.38-50, 2008.3

若林芳樹：地理空間の認知における地図の役割, Cognitive Studies, 15(1), pp38-50, 2008.3

8) Atsuyuki Okabe: Islamic Area Studies with Geographical Information Systems, Routledge, 2004

9) Bill Hillier: Space is the Machine-A Configurational Theory of Architecture, Cambridge University Press, 1999

10) Hasegawa, M. Kudo, A. Mori, S. and Oku, T.: Characteristics of Walking in everyday life in urban space - Characteristics of Action on difference of content of task -, Journal of the City Planning Institute of Japan, Vol.38-3, pp.427-432, 2003

長谷川昌史，工藤要紀，森傑，奥俊信 : 都市空間における日常生活での 歩行特性一タスク内容の差異からみたアクションの特性一, 日本都市計 画学会都市計画論文集, 第 38 巻, 第 3 号, pp.427-432, 2003.12 


\title{
A STUDY ON THE RELATIONSHIP BETWEEN STROLLING COURSE SELECTION AND PERSONAL FEATURE BY A METHOD OF DRAWING ONA MAP
}

\author{
Yang $H U^{* 1}$, Daisaku NISHINA ${ }^{* 2}$, Takahiro TANAKA*2 \\ and Wataru YAMASAKI*3 \\ ${ }^{* 1}$ Grad. Student, Graduate School of Eng., Hiroshima University, M.Eng. \\ *2 Prof, Graduate School of Eng. Hiroshima University, Dr.Eng. \\ *3 Japan Railway Construction, Transport and Technology Agency, M.Eng.
}

The course selection factors can be divided into two major categories, external condition such as street shape, street pattern, facilities, etc. and personal feature such as character, preference, etc. Different personal features are deemed to have a great impact on the course selection behavior. In order to create a good street space, it is necessary to consider the personal feature. However, studies from the perspective of personal feature have not been sufficiently accumulated. The purpose of this study is to clarify the relationship between course selection behavior and the personal feature, by analyzing the relationship between characteristics of the course selection and the difference of the personal feature.

The course selection experiments were carried out by the method of drawing a walking course on 12 blank maps with various streets patterns. As a reason, on the one hand, when people choose their course in the street space, the street itself is the most fundamental and most important element of the street space, such as street shape, street pattern, etc. So it is necessary to discuss people's attention to the street itself. The blank map can be used to simplify the street space and only show people the street itself. In this way, we can clearly grasp the relationship between the street itself and the course selection behavior. On the other hand, course selection behavior may change with different street characteristics. We can provide a variety of streets patterns through the blank maps. Based on this, we can clearly understand the course selection behavior.

About the experiment, the subjects were asked to draw courses, mark their interested places on those maps, and answer face sheets at the end of experiments. We analyzed the results of coures selected, the areas where the subjects were interested in and the subjects' personal feature respectively, then grasp the relationship among the three. Furthermore, we also discussed the differences of the course selected strategies of the subjects with different personal features. We show the knowledge provided from the experiment result below.

First, according to the result of course selected, the subjects were classified into 3 groups by Cluster Analysis. The subjects of Group 1 tended to walk a long distance and prefer narrow and complexed streets. The subjects of Group 2 had medium values of all the index of course selected were centered. In the subjects of Group 3, they prefered a short distance and simple street. As a feature of interested places in each group, Group 1 showed a wide range of interested places and have a large number of street units in interested places. In contrast, Group 3 showed a small range of interested places and tended to mark street blocks with special shape.

Second, regarding to personal features, they can be divided into 5 factors by Factor Analysis, namely space recognition, interest in strolling, interest in maps, sense of direction and curiosity. The subjects of Group 1 were most interested in strolling and they also have good spatial cognitive abilities. The spatial cognitive ability of Group 2 was the strongest among three groups, while the preference of strolling was slightly lower. The subjects of Group 3 lack preference of strolling and spatial cognition ability, but they have curiosity.

Finally, as a result of course selected strategy, the subjects of Group 1 tended to plan their course spread throughout the map. The subjects of Group 2 planned to choose curved streets and the streets where they were interested in. The subjects of Group 3 showed greater attention to the main streets or streets of special shapes. 